\title{
EVALUATION OF IN-VIVO BIOLOGICAL ACTIVITIES OF STERCULIA DIVERSIFOLIA (G. DON) IN RELEVANCE TO THE ISOLATED SECONDARY METABOLITES
}

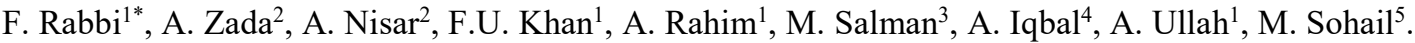 \\ ${ }^{1 *}$ Department of Pharmacy, Abasyn University Peshawar, Peshawar, 25000, Khyber Pakhtunkhwa, Pakistan. \\ ${ }^{2}$ Department of Pharmacy, University of Peshawar, Peshawar, 25120, Khyber Pakhtunkhwa, Pakistan. \\ ${ }^{3}$ Department of Microbiology and Biotechnology, Abasyn University Peshawar, Peshawar, 25000, Khyber Pakhtunkhwa, \\ Pakistan. \\ ${ }^{4}$ Department of Botany, Islamia College University Peshawar, Peshawar, 25120, Khyber Pakhtunkhwa, Pakistan. \\ ${ }^{5}$ School of Pharmacy, Yantai University, Yantai, Shandong, China. \\ Corresponding Author e-mail address: fazle.rabbi@abasyn.edu.pk
}

\begin{abstract}
Genus Sterculia possess various types of compounds which have therapeutic potential. This study was aimed to explore the anticonvulsant, CNS depressant, analgesic, anti-inflammatory and anti-pyretic activities of Sterculia diversifolia stem bark and leaves extracts in mice. The secondary metabolites in MESD (methanolic extract of Sterculia diversifolia) was characterized by UV, IR, ${ }^{1} \mathrm{H}-\mathrm{NMR},{ }^{13} \mathrm{C}$ NMR and $2 \mathrm{D}-\mathrm{NMR}$ spectra in combination with EI-MS spectrometric techniques. Anticonvulsant and CNS depressant effect of MESD was assessed using strychnine-induced convulsion and phenobarbitone-induced hypnotic protocol. Analgesic activity was performed by acetic acid induced writhing and hot plate test while anti-inflammatory and anti-pyretic activities were assessed by carrageenan induced right hind paw edema and brewer's yeast induced pyrexia. The isolation of compounds with different elucidation techniques $\left({ }^{1} \mathrm{H}-\mathrm{NMR},{ }^{13} \mathrm{C}\right.$ NMR and 2D-NMR spectra in combination with EI-MS spectrometric techniques) led to luteolin, isoquercitrin and ursolic acid. The current study results showed that crude MESD significantly $(p<0.05)$ delayed the onset, shortened the duration and offered protection against strychnine-induced convulsion. Crude MESD significantly $(p<0.05)$ prolonged the time of phenobarbitone-induced hypnosis. The analgesic response of crude MESD stem bark was more significant as compare to crude MESD leaves, while crude MESD also showed significant anti-inflammatory and antipyretic activity through dose dependent phenomenon. These significant results might be due to flavonoids (luteolin, isoquercitrin) and triterpenoids (ursolic acid) presence, though the involvement of other biologically active secondary metabolites cannot be overlooked.
\end{abstract}

Key words: Sterculia diversifolia; Anticonvulsant; CNS Depressant; Analgesic; Anti-inflammatory; Anti-pyretic.

https://doi.org/10.36899/JAPS.2021.1.0217

Published online August 26, 2020

\section{INTRODUCTION}

The herbal drugs which are natural source of treatment, has been overlooked for decades as a treatment strategy. In the recent years herbal medicines paid attention having less adverse effects as compared to synthetic drugs. These drugs bear various therapeutic applications (Gurib-Fakim, 2006). At present, globally there is an increasing demand for herbal medicine in the therapy of various ailments (Ur Rahman et al., 2017).

One of the most common neurological disorder is epilepsy, with an incidence of $3 \%$ in world population (Vyawahare et al., 2007). Anti-epileptic drugs presently available do not provide treatment nor relapse prevention and they are mostly associated with serious adverse effects, including chronic toxicity, teratogenicity and side effects on cognition and behavior (Dhayabaran et al., 2012). Many people living in developing countries still depend on herbal medicine for epilepsy management. About 400 herbal medicines are used in the management of epilepsy and the number is increasing day by day (Ghori et al., 2011). These herbal medicines are efficacious, cost effective and less number of side effects are the reason of their use in traditional medicine. These plants need to be explore as very limited efforts were made in past. CNS depressant agent is a type of drug that reduces neurotransmission levels, causing depression in various areas of brain. Various compounds and drugs i.e. zopiclone, eszopiclone and zolpidem are present in the market which depress the central nervous system and have hypnotic effects (Balaji et al., 2012).

Sterculia diversifolia is a tree of medium to tall size naturally found in variety of habitats in Australia from wetter coastal districts to semi-arid interiors of New South Wales, Victoria and Queensland (Buist et al., 2000). It has been cultivated for ornamental purpose in Louisiana, south-western Australia, California, South Africa, Arizona, South Asia, and Mediterranean countries. It has also been cultivated for ornamental purpose in Pakistan i.e. Peshawar (Jamshed et al., 2014) 
Medicinally, the plant bears immunomodulatory, cytotoxic, anti-glycation, larvicidal, anthelmintic, leishmanicidal, insecticidal and antioxidant activity (Rabbi et al., 2017, Rabbi et al., 2020b, Rabbi et al., 2020c). In earlier studies, few fatty acid constituents were isolated from Sterculia diversifolia (Salem et al., 2014). The present study was designed to investigate in-vivo biological activities of stem bark and leaves extracts of Sterculia diversifolia.

\section{MATERIALS AND METHODS}

Plant Material Collection: Plant material (stem bark and leaves) was collected from the botanical garden of Pakistan Forest Institute $\left(34^{\circ} 00^{\prime} 50.6^{\prime \prime N}, 71^{\circ} 29^{\prime} 03.0^{\prime \prime} \mathrm{E}\right)$, University of Peshawar, Pakistan, in September, 2014. The identification of plant was done by Ghulam Jelani (taxonomist) at Department of Botany, University of Peshawar. Under the reference No: Bot.20098 (PUP), a specimen was deposited in above mentioned institute herbarium (Rabbi et al., 2017).

Preparation of Extract: Sterculia diversifolia stem bark and leaves (17 and $13 \mathrm{~kg}$ respectively) were dried completely in shade at room temperature. These parts were then crushed to powder and macerated with $90 \%$ hydro-methanolic solvent $(2 \times 7$ days $)$. After maceration, filtration was conducted with Whatman grade-1 filter paper. Then under reduced pressure crude extracts were concentrated at $40^{\circ} \mathrm{C}$ using rotary evaporator (Rabbi et al., 2020b). Methanolic extract stem bark and leaves were obtained in $950 \mathrm{~g}$ and $1.2 \mathrm{~kg}$ quantity, respectively. MESD stem bark and leaves were mixed with distilled water $(2.5 \mathrm{~L})$ and soaked overnight. Fractionation was conducted with various organic solvents i.e. $n$-hexane (3 $\times 2.5 \mathrm{~L}), \mathrm{DCM}(3 \times 2.5 \mathrm{~L})$, EtoAc $(3 \times 2.5 \mathrm{~L})$ and $n-$ butanol $(3 \times 2.5 \mathrm{~L})$.

Isolation and Characterization: Ethyl acetate fraction was selected for isolation of compounds through column chromatography using normal phase silica gel. The elution was proceeded using various solvent systems with increasing polarity to get various sub-fractions i.e. $n$ hexane, $n$-hexane - EtoAc, EtoAc, EtoAc - methanol and methanol. Compound $1(456 \mathrm{mg})$ was obtained from subfraction 1, through repeated column chromatography using $n$-hexane-EtoAc (7:3) while sub-fraction 6 was rechromatographed on silica gel column using $n$-hexaneEtoAc (5:5) to obtained compound 2 (18 $\mathrm{mg})$. Compound $3(9 \mathrm{mg})$ was obtained from sub-fraction 2 through repeated column chromatography using hexane-EtoAc $(9: 1)$. These three compounds were purified using thin layer chromatography followed by treating with ceric sulphate and then heated. The structures of isolated compounds were elucidated using UV, IR, ${ }^{1} \mathrm{H}-\mathrm{NMR},{ }^{13} \mathrm{C}$ NMR and 2D-NMR analytical techniques (Rabbi et al., 2020a, Rabbi et al., 2020c).

\section{Phytochemical analysis}

MESD stem bark and leaves were preliminary evaluated through qualitative phytochemical analysis.

Total Flavonoids and Triterpenoids contents determination: For flavonoid contents determination, crude MESD stem bark and leaves (10 gm each) were continually extracted with $80 \%$ aqueous methanol $(2: 8)$ $(10 \mathrm{~mL})$ at ambient temperature. The obtained solutions were filtered with Whatman (\# 42) filter paper. The filtrate was then kept in a crucible. Extract was weighed after solvent evaporation by using water bath. (Khan et al., 2012).

To determine the triterpenoids contents, sample solution $(200 \mu \mathrm{L})$ was heated to evaporation in a volumetric flask $(10 \mathrm{~mL})$ using water-bath. After heating sulfuric acid $(10 \mathrm{~mL})$ and vanillin-acetic acid solution $(5 \% \mathrm{~W} / \mathrm{V})$ were added, mixed and incubated for $30 \mathrm{~min}$ at $70^{\circ} \mathrm{C}$. Solution was cooled and then diluted with acetic acid to $10 \mathrm{~mL}$. The absorbance was measured with spectrophotometer $(573 \mathrm{~nm})$. The standard ursolic acid calibration curve was used to determine the contents (Wei et al., 2015).

Experimental animals: BALB/c strains mice (Mus musculus) of both gender were used during pharmacological studies. The mice of BALB/c strains were purchased from animal house of National Institute of Health Islamabad. Housing of the animals was done under standard laboratory conditions (relative humidity $55-65 \%$, room temperature $23.0 \pm 2.0^{\circ} \mathrm{C}$ and 12 hours light: dark cycle). The age of mice used in this in vivo study was between 8-12 weeks, while these mice weight was in the range of $18-35 \mathrm{~g}$ as mentioned under each protocol. Standard ICDDR'B (International Centre for Diarrheal Disease Research, Bangladesh) formulated diet was provided to the mice and water ad libitum. Department of pharmacy, university of Peshawar provided the animal house facility in which in-vivo pharmacological experiments were performed. The ethical committee of Department of pharmacy, University of Peshawar, approved set of rules followed for animal experiments (Khan et al., 2010).

Drugs and chemicals: Strychnine hydrochloride (dissolved in normal saline), Phenobarbitone sodium (dissolved in normal saline). Reference drug, diazepam was obtained from local industry (Polyfine Chempharma Pvt. Ltd. Peshawar).

\section{Anticonvulsant activity}

Strychnine induced convulsions in mice: Mice weighing 18-22 gm body weight of both gender were distributed into eight groups $(n=6)$. Prior to the experiment, they were fasted overnight but water was supplied ad libitum. Group I (negative control) received normal saline (10 $\mathrm{ml} / \mathrm{kg}$ i.p.) while Group II (positive control) received 
diazepam (5 mg/kg, i.p.). Similarly group III - V and VI VIII animals received MESD stem bark and leaves (300, 400 and $500 \mathrm{mg} / \mathrm{kg}$, i.p.) respectively as mentioned in the literature. Mice of all groups received strychnine (4 $\mathrm{mg} / \mathrm{kg}$, i.p.) after $30 \mathrm{~min}$ of the above treatment, to induce convulsions. Then all the mice groups were observed for seizure induction and mortality (Vasconcelos et al., 2007).

\section{CNS depressant activity}

Phenobarbital-induced hypnosis time: CNS depressant effect of crude MESD stem bark and leaves were screened with the help of mice (18-22 gm) of either sex. For evaluation of the sleep inducing effect, mice were distributed into eight (8) groups $(n=6)$. Group I and Group II received normal saline $(10 \mathrm{ml} / \mathrm{kg}$, i.p. $)$ and diazepam $(4 \mathrm{mg} / \mathrm{kg}$, i.p.) respectively. Group III $-\mathrm{V}$ and group VI - VIII received crude MESD stem bark and leaves $(300,400$ and $500 \mathrm{mg} / \mathrm{kg}$ ) respectively. Phenobarbitone-Na (35 mg/kg, i.p.) was injected after 30 minutes of treatment to all mice groups. Onset and duration of sleep of each mouse was observed. Loss of postural reflux was confirmed by duration of sleep or hypnosis (Balaji et al., 2012, Hussain et al., 2016).

Analgesic activity: For screening the analgesic/ antinociceptive effect of crude MESD stem bark and leaves, acetic acid induced writhing and hot plate test were used. These are given below.

Acetic acid induced writhing: The crude MESD stem bark and leaves were studied for analgesic activity. $\mathrm{BALB} / \mathrm{c}$ mice (18-22 gm) of both gender were selected for this purpose. The mice were distributed into eight (8) different groups $(n=6)$. Group I (negative control) received normal saline $(10 \mathrm{ml} / \mathrm{kg}$ of body weight $)$ while group II (positive control) received Diclofenac-Na (10 $\mathrm{ml} / \mathrm{kg}$ of body weight). The animals were fasted ( 2 hours) prior experiment according to the recommended guidelines. Crude MESD stem bark at various doses (100, 200 and $400 \mathrm{mg} / \mathrm{kg}$ ) was injected to group III-V, while crude MESD leaves at same doses was administered to group VI-VIII respectively. Acetic acid (1\%, i.p.) was administered to all groups after $30 \mathrm{~min}$ of the above mentioned treatment. Writhing (abdominal constrictions) were started to count after $5 \mathrm{~min}$ of acetic acid administration for next 10 min (Khan et al., 2010). Percent (\%) analgesia was determined by formula given below.

$$
\begin{aligned}
\% \text { Analgesic effect } & =100-\frac{\text { No. of writhes in tested animals }}{\text { No. of writhes in control animals }} \\
& \times 100
\end{aligned}
$$

Hot plate test: $\mathrm{BALB} / \mathrm{c}$ mice weighing 18-22 gm were acclimatized one hour before start of experiment to the laboratory conditions. Food was stopped while water was available ad libitum. Pre-testing of mice were done on hot plate (Harvard apparatus) maintaining the temperature at
$55 \pm 0.1^{\circ} \mathrm{C}$. Those mice having latency time $>15$ seconds during pre-testing were rejected. Mice were distributed in eight groups having six mice in each. Group I (negative control) received normal saline $(10 \mathrm{ml} / \mathrm{kg}$, i.p.) while group II (positive control) received Tramadol $(30 \mathrm{mg} / \mathrm{kg}$, i.p.). Crude MESD stem bark at a dose of 100, 200 and $300 \mathrm{mg} / \mathrm{kg}$, i.p. was administered to group III - V respectively. Similarly crude MESD leaves at a dose of 100,200 and $300 \mathrm{mg} / \mathrm{kg}$, i.p. was administered to group VI-VIII respectively. Mice were kept on hot plate after 30 minutes of treatment and the latency time was measured in seconds. Latency time is the time in which animal remains on hot plate without jumping or flicking or licking of hind limb. For all mice, a cut-off time (30 seconds) were imposed in order to prevent tissue damage. Latency time was recorded at $0,30,60,90$ and $120 \mathrm{~min}$ for all groups (Muhammad et al., 2012).

Anti-inflammatory activity: Crude MESD stem bark and leaves were screened for anti-inflammatory effect. Carrageenan induced right hind paw edema protocol was used for this activity.

Carrageenan induced paw edema: Crude MESD stem bark and leaves were studied for anti-inflammatory activity. BALB/c mice of both gender (25-30 gm) were selected for this experiment. Mice were distributed into eight groups $(\mathrm{n}=6)$. Group I (negative control) received normal saline $(10 \mathrm{ml} / \mathrm{kg}$ ) while group II (positive control) received Diclofenac-Na $(10 \mathrm{mg} / \mathrm{kg})$ respectively. Crude MESD stem bark at a dose of 100, 200 and $300 \mathrm{mg} / \mathrm{kg}$ body weight was injected to group III - V respectively. Crude MESD leaves were injected to the group VI - VIII at a dose of 100,200 and $300 \mathrm{mg} / \mathrm{kg}$ body weight respectively. Carrageenan (1\%) was administered subcutaneously after $30 \mathrm{~min}$ of above mentioned treatment, in the right hind paw sub-planter tissue. Then after carrageenan injection, the anti-inflammatory activity was measured for 5 hours $(0,1,2,3,4$ and 5 hours) with the help of Plethysmometer (LE 7500 plan lab S.L) (Khan et al., 2009).

\section{Antipyretic activity}

Brewer's yeast induced pyrexia: Antipyretic effect of crude MESD stem bark and leaves were screened with the help of mice weighing 30-35 gm of either sex. Food was stopped (12 hours) while water was available $a d$ libitum. Mice were distributed into eight (8) groups of six mice each. Digital thermometer was used to record each mouse normal rectal temperature. Brewer's yeast aqueous suspension was administered subcutaneously to each mouse $(10 \mathrm{ml} / \mathrm{kg})$ for the induction of pyrexia. After 28 hrs, digital thermometer was used to record the rise in body temperature for each mouse. Mice showing at least $0.5^{\circ} \mathrm{C}$ rise of their body temperature were selected for the activity (Barkatullah et al., 2013). The doses to pyrexia induced mice of all groups were administered through 
intra-peritoneal route. Group I (negative control) received normal saline at a dose of $10 \mathrm{ml} / \mathrm{kg}$ while group II (positive control) received Paracetamol at a dose of 150 $\mathrm{mg} / \mathrm{kg}$ respectively. Crude MESD stem bark at a dose of 100,200 and $300 \mathrm{mg} / \mathrm{kg}$ of body weight was provided to group III - V. Similarly crude MESD leaves at a dose of 100,200 and $300 \mathrm{mg} / \mathrm{kg}$ of body weight was provided to group VI - VIII respectively. After the administration of normal saline, drug and crude extract, mice rectal temperature was noted at $1,2,3,4$ and $5^{\text {th }}$ hour for all groups.

Statistical analysis: GraphPad Prism (Version 7.0) software was used for the data evaluation using one way ANOVA followed by Dunnett's Multiple Comparison test. Mean values \pm SEM were calculated for each parameter, while level of significance was kept at $p<$ 0.05 .

\section{RESULTS}

Qualitative phytochemical analysis: The MESD stem bark and leaves were screened for various phytochemicals presence through different methods as mentioned in the literature. From results it is confirmed that carbohydrates, alkaloids, sterols, steroids, saponins, glycosides, phenol's, flavonoids, terpenoides, tannins, phloba-tannins and vitamin $\mathrm{C}$ are present in stem bark and leaves. Coumarins are also present in leaves but absent in stem bark, while amino acids and proteins are also absent in both parts.

\section{Quantitative phytochemical analysis}

Total flavonoid contents: Total flavonoid contents were quantified in crude methanol extract, $n$-hexane, dichloromethane, ethyl acetate, $n$-butanol and aqueous fraction (Figure 1). The maximum flavonoids contents were shown in ethyl acetate fraction followed by DCM and crude methanol extract.

Total Triterpenoids contents: Total triterpenoids contents were quantified in crude methanol extract, $n$ hexane, DCM, ethyl acetate, $n$-butanol and aqueous fraction (Figure 2). The maximum triterpenoids contents were found in ethyl acetate fraction followed by DCM and crude methanol extract.

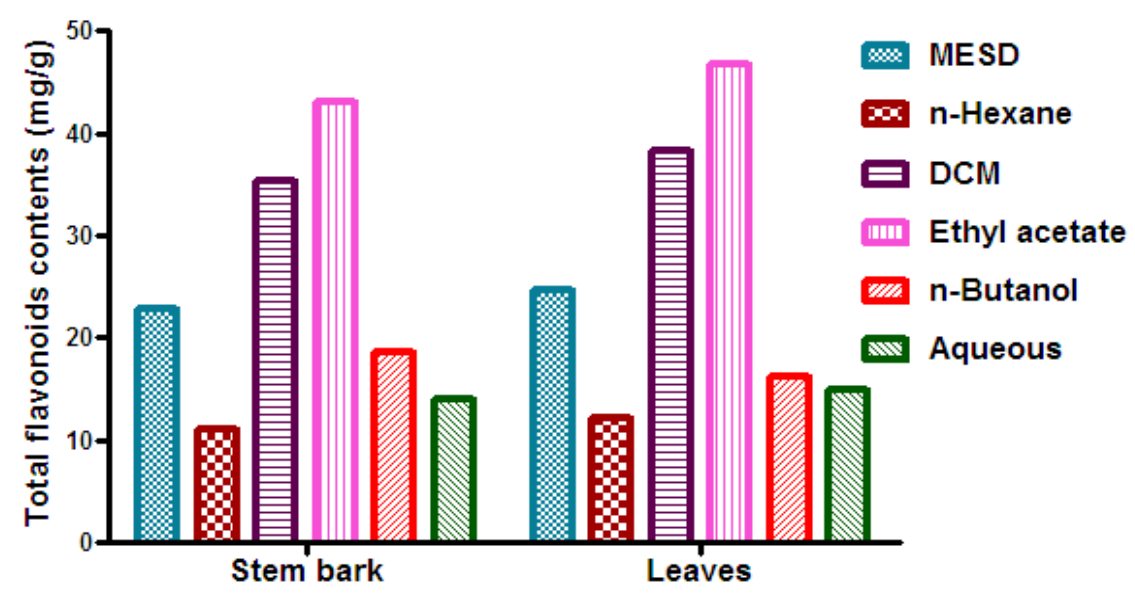

Figure 1. Total flavonoids contents of MESD and its fractions of stem bark and leaves.

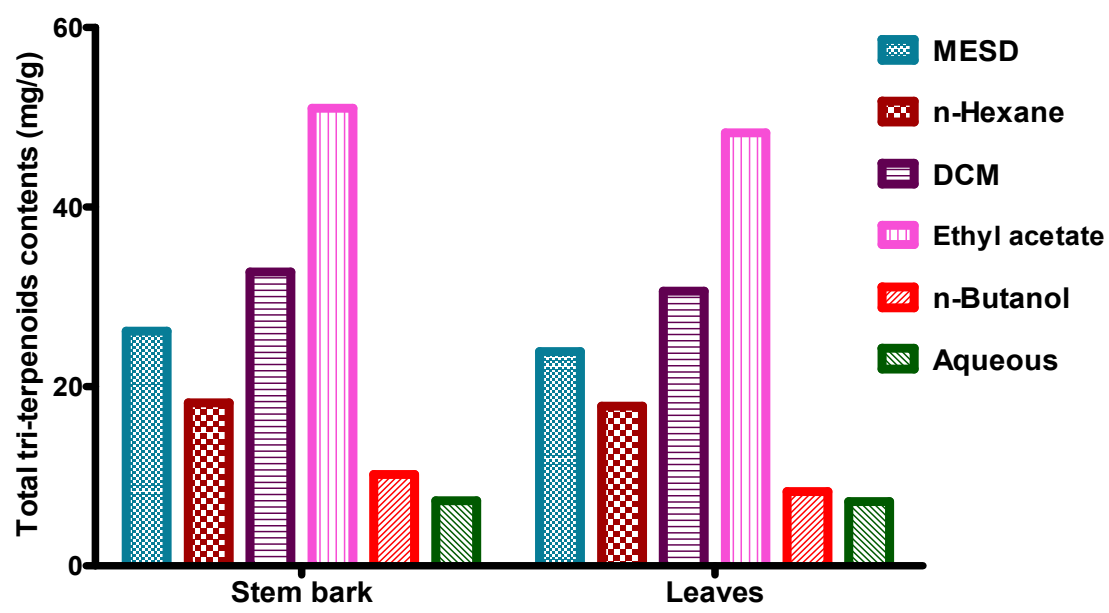

Figure 2. Total triterpenoids contents of MESD and its fractions of stem bark and leaves. 
Isolation and structure elucidation: Ethyl acetate fraction was selected for further detailed isolation and structural elucidation techniques that results compound 1 (luteolin), compound 2 (isoquercitrin) and compound 3 (Ursolic acid) respectively (Figure 3). Luteolin showed molecular ion peak at $\mathrm{m} / \mathrm{z}$ at 286.1, and having a molecular formula of $\mathrm{C}_{15} \mathrm{H}_{10} \mathrm{O}_{6}$. Isoquercitrin showed molecular ion peak $[\mathrm{M}-\mathrm{H}]$ at $\mathrm{m} / \mathrm{z} 464.4$ and having a molecular formula of $\mathrm{C}_{21} \mathrm{H}_{20} \mathrm{O}_{12}$. Ursolic acid showed molecular ion peak at $\mathrm{m} / \mathrm{z} 456.4$ and having molecular formula of $\mathrm{C}_{30} \mathrm{H}_{48} \mathrm{O}_{3}$.<smiles>O=c1cc(-c2ccc(O)c(O)c2)oc2cc(O)cc(O)c12</smiles>

(A)<smiles>O=c1c(O[C@@H]2O[C@H](CO)[C@@H](O)[C@H](O)[C@H]2O)c(-c2ccc(O)c(O)c2)oc2cc(O)cc(O)c12</smiles>

(B)

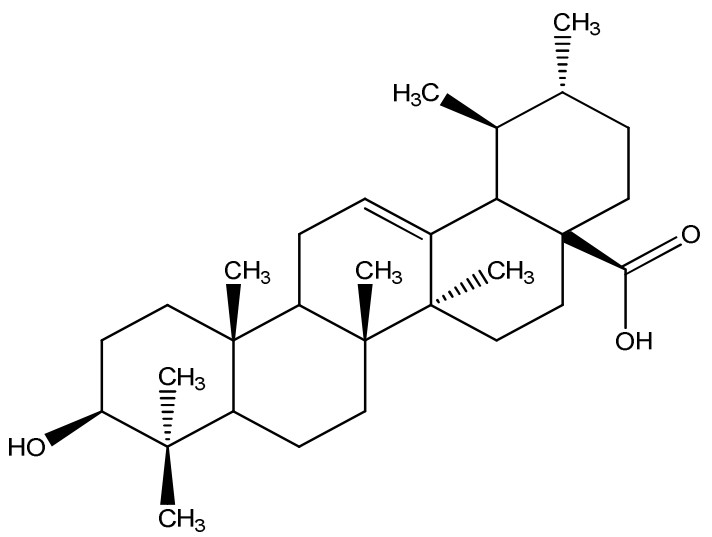

(C)

Figure 3. Structures of isolated compounds from MESD; (A) Luteolin; (B) Isoquercitrin; (C) Ursolic acid

Anticonvulsant Activity: Crude MESD stem bark and leaves significantly $(p<0.05)$ prolonged the onset of action of convulsion and shortened the duration of action of convulsion seizure. At a dose of $500 \mathrm{mg} / \mathrm{kg}$, of both stem bark and leaves extract, highly significantly $(p<$ 0.001 ) produced prolongation of onset of convulsion. Onset and duration of convulsion in diazepam treated group was not observed. The onset and duration of convulsion of MESD III and VI was more significantly treated as compared to MESD I, II, IV and V respectively. All of the animals were protected from death at a dose $500 \mathrm{mg} / \mathrm{kg}$ of both stem bark and leaves (Table 1) respectively.

CNS Depressant activity: The crude MESD stem bark and leaves were found to exhibit hypnotic property (Table 2). Both of the extracts prolonged the duration of sleeping time by increasing dose (dose dependent). The onset and duration of sleep in positive control group was 9.5 minutes and 115.3 minutes respectively. The onset and duration of sleep of MESD-III and VI was more significant as compared to MESD-I, II, IV and V.

\section{Analgesic activity}

Acetic acid induced writhing: Crude MESD stem bark and leaves in different test groups at various doses (100, 200 and $400 \mathrm{mg} / \mathrm{kg}$, i.p.) showed decrease in number of writhing. The mean writhing in saline treated group was $53.17 \pm 5.74$. The percent analgesia produced by various test doses of crude MESD stem bark was 36.05\% (100 $\mathrm{mg} / \mathrm{kg}), 76.81 \%(200 \mathrm{mg} / \mathrm{kg})$ and $86.84 \%(400 \mathrm{mg} / \mathrm{kg})$. Similarly the percent analgesia produced by different test doses of crude MESD leaves was 33.85\% (100 mg $/ \mathrm{kg})$, $68.97 \%$ (200 mg/kg) and 80.87\% (400 mg/kg). The effect produced by crude MESD stem bark and leaves was dose dependent. Diclofenac sodium (standard drug) showed 
maximum percent inhibition $(81.19 \%)$ at a dose of 10 $\mathrm{mg}$. This inhibition is greater than the highest dose (400 $\mathrm{mg} / \mathrm{kg}$ ) of crude MESD leaves while less than crude
MESD stem bark. The percent (\%) decrease in writhing by the Diclofenac sodium and crude MESD stem bark and leaves is represented in table 3 .

Table 1. Effect of crude MESD stem bark and leaves on Strychnine-induce convulsion.

\begin{tabular}{llccccc}
\hline \multicolumn{1}{c}{ Treatment } & & $\begin{array}{c}\text { Dose } \\
(\mathbf{m g} / \mathbf{k g})\end{array}$ & $\begin{array}{c}\text { Onset of convulsion } \\
\text { (s) }\end{array}$ & $\begin{array}{c}\text { Duration of } \\
\text { convulsion (s) }\end{array}$ & $\begin{array}{c}\text { Percent } \\
\text { Protection }\end{array}$ & $\begin{array}{c}\text { Percent } \\
\text { death }\end{array}$ \\
\hline Saline & 10 & $265.0 \pm 27.29$ & $201.7 \pm 11.67$ & 0 & 100 \\
Standard (Diazepam) & 5 & $-^{* * *}$ & $-^{* * *}$ & 100 & 0.0 \\
Stem bark & MESD-I & 300 & $362.5 \pm 25.02^{*}$ & $162.0 \pm 1.065^{*}$ & 0 & 100 \\
& MESD-II & 400 & $403.3 \pm 15.20^{* *}$ & $148.2 \pm 2.040^{* *}$ & 33.33 & 66.67 \\
Leaves & MESD-III & 500 & $736.2 \pm 15.89^{* * *}$ & $102.2 \pm 2.372^{* * *}$ & 100 & 0 \\
& MESD-IV & 300 & $293.0 \pm 16.11^{* *}$ & $155.7 \pm 2.985^{* *}$ & 17 & 83 \\
& MESD-V & 400 & $411.5 \pm 11.44^{* * *}$ & $112.2 \pm 1.851^{* * *}$ & 50 & 50 \\
\hline
\end{tabular}

Values are expressed as mean \pm SEM from six mice. $* p<.05,{ }^{* *} p<0.01,{ }^{* * *} p<0.001$, significant difference compared to control

(ANOVA followed by Dunnett's multiple comparisons test).

Table 2. Effect of crude MESD stem bark and leaves on phenobarbitone-induce sleep.

\begin{tabular}{lcccc}
\hline \multicolumn{1}{c}{ Treatment } & $\begin{array}{c}\text { Dose } \\
(\mathbf{m g} / \mathbf{k g})\end{array}$ & $\begin{array}{c}\text { Onset of sleep } \\
(\mathbf{m i n})\end{array}$ & $\begin{array}{c}\text { Duration of sleep } \\
(\mathbf{m i n})\end{array}$ \\
\hline Saline & 10 & $35.5 \pm 0.8851$ & $47.33 \pm 1.647$ \\
Standard (Diazepam) & 4 & $9.5 \pm 0.7638^{* * *}$ & $115.3 \pm 1.308^{* * *}$ \\
Stem bark & MESD-I & 300 & $29.17 \pm 0.4014$ & $52.67 \pm 1.202$ \\
& MESD-II & 400 & $26.50 \pm 0.7638^{*}$ & $54.33 \pm 1.229^{*}$ \\
Leaves & MESD-III & 500 & $15.50 \pm 0.7638^{* * *}$ & $95.50 \pm 0.7638^{* * *}$ \\
& MESD-IV & 300 & $28.50 \pm 0.8466^{*}$ & $53.50 \pm 1.088^{*}$ \\
& MESD-V & 400 & $25.83 \pm 1.078^{* *}$ & $56.33 \pm 1.116^{* *}$ \\
\hline
\end{tabular}

Values are expressed as mean \pm SEM from six mice. $* p<.05,{ }^{* *} p<0.01,{ }^{* * *} p<0.001$, significant difference compared to control through ANOVA followed by Dunnett's multiple comparisons test.

Table 3. Analgesic activity (Acetic acid induced writhing) of crude MESD stem bark and leaves.

\begin{tabular}{|c|c|c|c|c|}
\hline \multicolumn{2}{|c|}{ Treatment } & \multirow{2}{*}{$\begin{array}{c}\begin{array}{c}\text { Dose } \\
(\mathrm{mg} / \mathrm{kg})\end{array} \\
10\end{array}$} & \multirow{2}{*}{$\begin{array}{c}\begin{array}{c}\text { Number of writhing } \\
\text { (10 } \text { min) }\end{array} \\
53.17 \pm 5.74\end{array}$} & \multirow{2}{*}{$\begin{array}{c}\text { Percent Analgesia } \\
--\end{array}$} \\
\hline Saline & & & & \\
\hline \multirow{2}{*}{\multicolumn{2}{|c|}{ Standard (Diclofenac-Na) }} & 10 & $10.00 \pm 2.07^{* * *}$ & 81.19 \\
\hline & & 100 & $34 \pm 2.84^{* *}$ & 36.05 \\
\hline & MESD-II & 200 & $12.33 \pm 2.23^{* * *}$ & 76.81 \\
\hline & MESD-III & 400 & $07.00 \pm 1.15^{* * *}$ & 86.84 \\
\hline \multirow[t]{3}{*}{ Leaves } & MESD-IV & 100 & $35.17 \pm 1.89^{* *}$ & 33.85 \\
\hline & MESD-V & 200 & $16.50 \pm 1.59^{* * *}$ & 68.97 \\
\hline & MESD-VI & 400 & $10.17 \pm 1.45^{* * *}$ & 80.87 \\
\hline \multicolumn{5}{|c|}{$\begin{array}{l}\text { Values are reported as mean } \pm \text { S.E.M. for group }(\mathrm{n}=6) \text {. Data was analyzed by ANOVA followed by Dunnett's test. }{ }^{* *} p<0.05 \text {, } \\
{ }^{*} p<0.01,{ }^{* * *} p<0.001 \text { in comparison to control. }\end{array}$} \\
\hline \multicolumn{3}{|c|}{$\begin{array}{l}\text { Hot Plate Test: The crude methanolic extract of Sterculia } \\
\text { diversifolia stem bark and leaves were screened for anti- } \\
\text { nociceptive response. The analgesic effect of both } \\
\text { extracts are given in table } 4 \text {. The latency of nociceptive } \\
\text { response in seconds of Sterculia diversifolia stem bark } \\
\text { after } 30 \text { minutes was } 9.92 \pm 1.35,11.04 \pm 1.28 \text { and } 16.52 \\
\pm 2.16 \text { respectively at } 100,200 \text { and } 300 \mathrm{mg} / \mathrm{kg} \text { dose. The }\end{array}$} & \multicolumn{2}{|c|}{$\begin{array}{l}\text { reduction in algesia after } 1 \text { hour of treatment for test } \\
\text { doses of crude MESD stem bark }(100,200 \text { and } 300 \\
\mathrm{mg} / \mathrm{kg}) \text { was } 13.28 \pm 0.85,16.39 \pm 1.31 \text { and } 18.24 \pm 1.82 \\
\text { sec respectively. The nociceptive response observed at } 90 \\
\text { minutes for all test doses of stem bark was } 13.25 \pm 0.56 \text {, } \\
16.27 \pm 1.06 \text { and } 18.11 \pm 1.30 \text { sec. At } 2 \text { hours latency of } \\
\text { nociceptive response showed by all test doses but more }\end{array}$} \\
\hline
\end{tabular}


significantly at a dose of $300 \mathrm{mg} / \mathrm{kg}$ was $18.02 \pm 0.97 \mathrm{sec}$ respectively $(p<0.001)$. The latency of nociceptive response in seconds of Sterculia diversifolia leaves after 30 minutes was $9.72 \pm 1.43,14.20 \pm 1.39$ and $17.87 \pm$ 1.35 respectively at 100,200 and $300 \mathrm{mg} / \mathrm{kg}$ dose. After 1 hour of treatment the reduction in algesia for test doses of crude MESD leaves $(100,200$ and $300 \mathrm{mg} / \mathrm{kg})$ was $13.03 \pm 1.26,17.45 \pm 1.23$ and $20.05 \pm 1.38 \mathrm{sec}$ respectively. The nociceptive response observed at 90 minutes for all test doses of leaves was $13.02 \pm 1.60$, $17.37 \pm 1.17$ and $19.93 \pm 1.78 \mathrm{sec}$. At 2 hours latency of nociceptive response was showed by all test doses of leaves extract but more significantly at a dose of 300 $\mathrm{mg} / \mathrm{kg}$ was $19.89 \pm 0.68$ respectively $(p<0.001)$. Tramadol (standard drug) showed its analgesic effect in 30 minutes.

Table 4. Analgesic Activity (Hot plate test) of crude MESD stem bark and leaves.

\begin{tabular}{|c|c|c|c|c|c|c|c|}
\hline \multicolumn{2}{|c|}{ Treatment } & \multirow{2}{*}{$\begin{array}{c}\text { Dose } \\
(\mathrm{mg} / \mathrm{kg})\end{array}$} & \multicolumn{5}{|c|}{ Latency of nociceptive response in seconds $($ mean \pm SEM) } \\
\hline & & & $\mathbf{0} \min$ & 30 min & $60 \mathrm{~min}$ & $90 \mathrm{~min}$ & $120 \mathrm{~min}$ \\
\hline Saline & & -- & $9.17 \pm 0.40$ & $9.27 \pm 0.85$ & $9.98 \pm 0.85$ & $10.00 \pm 0.97$ & $10.05 \pm 0.59$ \\
\hline Standard & & 30 & $9.00 \pm 0.26$ & $25.15 \pm 1.90^{* * *}$ & $25.33 \pm 1.58^{* * *}$ & $25.30 \pm 1.86^{* * *}$ & $25.38 \pm 1.69^{* * *}$ \\
\hline \multirow[t]{3}{*}{ Stem bark } & MESD-I & 100 & $9.67 \pm 0.21$ & $9.92 \pm 1.35$ & $13.28 \pm 0.85$ & $13.25 \pm 0.56$ & $13.23 \pm 0.81$ \\
\hline & MESD-II & 200 & $9.17 \pm 0.70$ & $11.04 \pm 1.28$ & $16.39 \pm 1.31^{* *}$ & $16.27 \pm 1.06^{* *}$ & $16.23 \pm 0.69^{* * * *}$ \\
\hline & MESD-III & 300 & $9.33 \pm 0.42$ & $16.52 \pm 2.16^{*}$ & $18.24 \pm 1.82^{* * *}$ & $18.11 \pm 1.30^{* * *}$ & $18.02 \pm 0.97^{* * *}$ \\
\hline \multirow[t]{3}{*}{ Leaves } & MESD-IV & 100 & $9.50 \pm 0.34$ & $9.72 \pm 1.43$ & $13.03 \pm 1.26$ & $13.02 \pm 1.6$ & $12.95 \pm 0.95$ \\
\hline & MESD-V & 200 & $9.83 \pm 0.54$ & $14.20 \pm 1.39$ & $17.45 \pm 1.23^{* *}$ & $17.37 \pm 1.17^{* *}$ & $17.35 \pm 1.63^{* * *}$ \\
\hline & MESD-VI & 300 & $10.33 \pm 0.71$ & $17.87 \pm 1.35^{* *}$ & $20.05 \pm 1.38^{* * *}$ & $19.93 \pm 1.78^{* * *}$ & $19.89 \pm 0.68^{* * *}$ \\
\hline
\end{tabular}

Values are reported as mean \pm S.E.M. for group of 6 animals. The data was analyzed by ANOVA followed by Dunnett's test.

${ }^{*} p<0.05,{ }^{* *} p<0.01,{ }^{* * *} p<0.001$ in comparison to control.

Anti-Inflammatory activity

Carrageenan induced paw edema: The crude extract of Sterculia diversifolia stem bark and leaves $(100,200$ and $300 \mathrm{mg} / \mathrm{kg}$ ) was evaluated for possible anti-inflammatory activity. The obtained results are shown in table 5. Carrageenan alone treated animals exhibited significant $(p<0.001)$ paw edema after 1 hour of administration and this condition remained persistent for 5 hours. Pretreatment with MESD stem bark and leaves significantly alleviated the carrageenan elicited paw edema after 2 and 3 hours at doses of $100 \mathrm{mg} / \mathrm{kg}(p<0.05$ and $p<0.01)$, $200 \mathrm{mg} / \mathrm{kg}(p<0.05$ and $p<0.001)$ and $300 \mathrm{mg} / \mathrm{kg}(p<$ 0.01 and $p<0.001)$ showing same results. Maximum anti-inflammatory effect was demonstrated by crude MESD-III $(300 \mathrm{mg} / \mathrm{kg})$ at $3^{\text {rd }}$ hour $(\mathrm{p}<0.001)$. However at dose of $100 \mathrm{mg} / \mathrm{kg}$ of stem bark and leaves, a nonsignificant reduction was observed after 5 hours of carrageenan administration. While at dose $200 \mathrm{mg} / \mathrm{kg}$ and $300 \mathrm{mg} / \mathrm{kg}$ of MESD stem bark and leaves after 5 hours, moderate to highly significant alleviation of paw edema. Maximum anti-inflammatory effect was demonstrated by crude MESD-VI $(300 \mathrm{mg} / \mathrm{kg})$ at $4^{\text {th }}$ hour $(p<0.001)$. Moreover, at a dose of $10 \mathrm{mg} / \mathrm{kg}$ diclofenac-Na (standard) produced significant (moderate-high) paw edema alleviation after 1 hour $(p<0.01)$ and $2-5$ hours $(p$ $<0.001)$.

Table 5. Anti-inflammatory activity (Carrageenan induced paw edema model) stem bark and leaves.

\begin{tabular}{|c|c|c|c|c|c|c|c|c|}
\hline \multicolumn{2}{|c|}{ Treatment } & $\begin{array}{c}\begin{array}{c}\text { Dose } \\
\text { (mg/ } \\
\text { kg) }\end{array} \\
\end{array}$ & O hr & $1 \mathrm{hr}$ & $2 \mathrm{hr}$ & $3 \mathrm{hr}$ & $4 \mathrm{hr}$ & $5 \mathrm{hr}$ \\
\hline \multicolumn{2}{|l|}{ Saline } & -- & $0.177 \pm 0.014$ & $0.233 \pm 0.022$ & $0.243 \pm 0.019$ & $0.246 \pm 0.017$ & $0.245 \pm 0.018$ & $0.245 \pm 0.022$ \\
\hline \multicolumn{2}{|l|}{ Standard } & 10 & $0.170 \pm 0.019$ & $0.145 \pm 0.013^{* *}$ & $0.130 \pm 0.019^{* * *}$ & $0.095 \pm 0.012^{* * *}$ & $0.105 \pm 0.012^{* * *}$ & $0.099 \pm 0.022^{* * *}$ \\
\hline & MESD-I & 100 & $0.145 \pm 0.015$ & $0.170 \pm 0.010$ & $0.160 \pm 0.013^{*}$ & $0.158 \pm 0.009^{* *}$ & $0.173 \pm 0.008^{*}$ & $0.183 \pm 0.015$ \\
\hline \multirow[t]{2}{*}{ Bark } & MESD-II & 200 & $0.193 \pm 0.017$ & $0.181 \pm 0.020$ & $0.173 \pm 0.023^{*}$ & $0.128 \pm 0.023^{* * *}$ & $0.143 \pm 0.024^{* * *}$ & $0.150 \pm 0.023^{* *}$ \\
\hline & MESD-III & 300 & $0.193 \pm 0.016$ & $0.153 \pm 0.021^{*}$ & $0.137 \pm 0.019^{* *}$ & $0.078 \pm 0.010^{* * *}$ & $0.100 \pm 0.007^{* * *}$ & $0.112 \pm 0.009^{* * *}$ \\
\hline \multirow[t]{3}{*}{ Leaves } & MESD-IV & 100 & $0.140 \pm 0.008$ & $0.192 \pm 0.004$ & $0.188 \pm 0.003^{*}$ & $0.188 \pm 0.005^{* *}$ & $0.198 \pm 0.004^{*}$ & $0.200 \pm 0.004$ \\
\hline & MESD-V & 200 & $0.187 \pm 0.003$ & $0.193 \pm 0.002$ & $0.187 \pm 0.002^{*}$ & $0.170 \pm 0.004^{* * *}$ & $0.177 \pm 0.003^{* * *}$ & $0.180 \pm 0.002^{*}$ \\
\hline & MESD-VI & 300 & $0.183 \pm 0.016$ & $0.180 \pm 0.00^{*}$ & $0.172 \pm 0.004^{* *}$ & $0.150 \pm 0.004^{* * *}$ & $0.148 \pm 0.003^{* * *}$ & $0.153 \pm 0.003^{* * *}$ \\
\hline
\end{tabular}

Values are reported as mean \pm SEM. for group of six animals. The data was analyzed by ANOVA followed by Dunnett's test. Asterisks indicated statistically significant values from control. ${ }^{*} p<0.05,{ }^{* *} p<0.01,{ }^{* * *} p<0.001$.

\section{Antipyretic activity}

Brewer's yeast induced pyrexia: The crude extract of Sterculia diversifolia stem bark and leaves was screened for antipyretic activity. The antipyretic effect produced by crude MESD stem bark and leaves are given in table 6 , respectively. Brewer's yeast induced body temperature significantly $(p<0.001)$ and throughout the 5 hours of activity, the temperature remained elevated. After 1 hour 
of treatment, pyrexia was reduced significantly $(p<$ 0.001 ) with crude MESD stem bark at dose of $300 \mathrm{mg} / \mathrm{kg}$. After 2 hour of treatment similar effect was observed with MESD stem bark at $300 \mathrm{mg} / \mathrm{kg}(p<0.001)$. After 3 hours, antipyretic effect (highly significant) was observed with the $200 \mathrm{mg} / \mathrm{kg}(p<0.001)$ and $300 \mathrm{mg} / \mathrm{kg}(p<$ 0.001 ) doses of MESD stem bark and this effect persisted till the $5^{\text {th }}$ hour. The $100 \mathrm{mg} / \mathrm{kg}$ dose of MESD stem bark was less significant from $1^{\text {st }}$ hour $(p<0.05)$ till $5^{\text {th }}$ hour $(p<0.01)$. It means increase the dose from 100 to 300 $\mathrm{mg} / \mathrm{kg}$, the drug level of significance also increases vice versa.
The crude MESD leaves showed less significant reduction $(p<0.05)$ in pyrexia after 1 hour of treatment at dose of $300 \mathrm{mg} / \mathrm{kg}$. Similar protective effect was shown after 2 hour of treatment with MESD leaves at 100 $\mathrm{mg} / \mathrm{kg}$ and $200 \mathrm{mg} / \mathrm{kg}(p<0.05)$ dose. While at a dose of $300 \mathrm{mg} / \mathrm{kg}$, highly significant antipyretic effect $(p<$ 0.001 ) was observed. After 3 hours, highly significant antipyretic effect was observed with the $300 \mathrm{mg} / \mathrm{kg}(p<$ $0.001)$ dose of MESD leaves and this effect persisted till the $5^{\text {th }}$ hour.

The standard Paracetamol at $150 \mathrm{mg} / \mathrm{kg}$ produced a strong antipyretic effect $(p<0.001)$ throughout the five hours study period.

Table 6. Antipyretic activity (Brewer's yeast induced pyrexia) of crude MESD stem bark and leaves

\begin{tabular}{|c|c|c|c|c|c|c|c|c|c|}
\hline \multirow{3}{*}{\multicolumn{2}{|c|}{ Treatment }} & \multirow{3}{*}{$\begin{array}{c}\text { Dose } \\
\text { (mg/ } \\
\text { kg) }\end{array}$} & \multicolumn{7}{|c|}{ Rectal temperature $\left({ }^{\circ} \mathrm{C}\right)$} \\
\hline & & & \multirow{2}{*}{$\begin{array}{l}\text { Normal } \\
\text { Temp }\end{array}$} & \multirow{2}{*}{$\begin{array}{c}\text { After } 24 \\
\text { hours }\end{array}$} & \multicolumn{5}{|c|}{ After administration of drug } \\
\hline & & & & & $1 \mathrm{hr}$ & $2 \mathrm{hr}$ & $3 \mathrm{hr}$ & $4 \mathrm{hr}$ & $5 \mathrm{hr}$ \\
\hline \multirow{2}{*}{\multicolumn{2}{|c|}{$\begin{array}{l}\text { Saline } \\
\text { Paracetamol }\end{array}$}} & 10 & $36.37 \pm 0.32$ & $38.95 \pm 0.26$ & $39.02 \pm 0.27$ & $39.07 \pm 0.13$ & $39.13 \pm 0.22$ & $39.33 \pm 0.16$ & $39.53 \pm 0.16$ \\
\hline & & 150 & $36.62 \pm 0.28$ & $38.65 \pm 0.27$ & $37.70 \pm 0.14^{* * *}$ & $37.03 \pm 0.37^{* * *}$ & $36.72 \pm 0.36^{* * *}$ & $36.45 \pm 0.43^{* * *}$ & $36.48 \pm 0.45^{* * *}$ \\
\hline \multirow{3}{*}{ Е } & MESD-I & 100 & $36.43 \pm 0.57$ & $37.65 \pm 0.30$ & $38.27 \pm 0.11^{*}$ & $37.53 \pm 0.32^{* *}$ & $37.28 \pm 0.19^{* *}$ & $37.22 \pm 0.55^{* *}$ & $37.30 \pm 0.36^{* *}$ \\
\hline & MESD-II & 200 & $36.90 \pm 0.54$ & $37.77 \pm 0.34$ & $38.15 \pm 0.10^{* *}$ & $37.40 \pm 0.41^{* *}$ & $37.12 \pm 0.54^{* * *}$ & $37.02 \pm 0.15^{* * *}$ & $37.10 \pm 0.31^{* * *}$ \\
\hline & MESD-III & 300 & $36.88 \pm 0.79$ & $36.72 \pm 0.46$ & $37.80 \pm 0.26^{* * *}$ & $37.17 \pm 0.25^{* * *}$ & $37.08 \pm 0.18^{* * *}$ & $36.98 \pm 0.43^{* * *}$ & $37.07 \pm 0.58^{* * *}$ \\
\hline \multirow{3}{*}{ 离 } & MESD-IV & 100 & $37.05 \pm 0.20$ & $38.88 \pm 0.14$ & $38.72 \pm 0.34$ & $37.87 \pm 0.24^{*}$ & $37.55 \pm 0.19^{*}$ & $37.52 \pm 0.38^{* *}$ & $37.60 \pm 0.59^{* *}$ \\
\hline & MESD-V & 200 & $36.83 \pm 0.48$ & $38.97 \pm 0.18$ & $38.72 \pm 0.21$ & $37.82 \pm 0.20^{*}$ & $37.42 \pm 0.34^{* *}$ & $37.37 \pm 0.31^{* *}$ & $37.38 \pm 0.51^{* *}$ \\
\hline & MESD-VI & 300 & $36.88 \pm 0.47$ & $38.93 \pm 0.23$ & $38.07 \pm 0.21^{*}$ & $37.10 \pm 0.50^{* * *}$ & $36.88 \pm 0.57^{* * *}$ & $36.80 \pm 0.53^{* * *}$ & $36.83 \pm 0.39^{* * *}$ \\
\hline
\end{tabular}

Values are expressed as mean \pm SEM. ANOVA followed by Dunnett's post hoc test. ${ }^{*} p<0.05,{ }^{* * *} p<0.01,{ }^{* * *} p<0.001$ compared to brewer's yeast alone treated group $(n=6)$

\section{DISCUSSION}

Plants produce biologically active constituents of various chemical classes which are deposited in their specific parts. Phytochemical tests revealed carbohydrates, alkaloids, sterols, steroids, saponins, glycosides, phenol's, flavonoids, terpenoides, tannins, phloba-tannins and vitamin $\mathrm{C}$ presence. Coumarins are present in leaves but absent in stem bark, while amino acids and proteins showed negative results in both parts. The presence of compounds of different chemical classes such as flavonoids, alkaloids, glycosides, tannins, steroids and coumarins validates its potent pharmacological active potential (Alam et al., 2016).

In the present study, three biologically active secondary metabolites were isolated. These compounds belongs to flavonoids (Luteolin and isoquercitrin) and triterpenoids (ursolic acid) classes. Luteolin possess anticonvulsant (Shaikh et al., 2013), CNS depressant (Tambe et al., 2017), anti-nociceptive (Fan et al., 2018) and anti-inflammatory (Fan et al., 2018) properties as reported in the literature. Isoquercitrin has anticonvulsant, CNS depressant (Guo et al., 2011) and anti-inflammatory (Rogerio et al., 2007) activities. In addition, ursolic acid have also been reported to possess anticonvulsant (Nieoczym et al., 2018), CNS depressant (Taviano et al.,
2007) and anti-inflammatory (Rai et al., 2019) activities. Keeping in view, the potent anticonvulsant, CNS depressant, analgesic and anti-inflammatory effects of MESD, it might be due to the presence of luteolin, isoquercitrin and ursolic acid in Sterculia diversifolia. However other secondary metabolites cannot be overlooked in the intervention of convulsion, seizure, insomnia, pain, inflammation and fever.

Crude MESD stem bark and leaves showed anticonvulsant effect by significantly $(\mathrm{p}<0.05)$ prolong the onset of action of convulsion and shortened the duration of action. The onset and duration of convulsion of MESD III-VI was more significant as compared to MESD I, II, VI and V respectively. Therefore a systemic approach should be made to find out the effectiveness of plant products as an anticonvulsant agent. Strychnine induced seizures follows the mechanism of antagonism of glycine receptors. Glycine receptors are distributed in higher brain areas, brainstem and spinal cord (Vasconcelos et al., 2007). This thereby nullify spinal reflexes and causing increased muscle tone, motor disturbance, visual hyperactivity, sensory and acoustic perception, tonic convulsion and death through paralysis of cardiac system, respiratory system and spinal cord (Chokroverty et al., 2017). It is concluded from our data that strychnine-induced convulsion is suppressed partially 
by crude extract of Sterculia diversifolia stem bark and leaves.

The crude MESD stem bark and leaves showed sedative and hypnotic potential by prolonging phenobarbitone-induced sleeping time. Dose dependent phenomenon was shown by both of the extracts and thus prolonged the duration of sleeping time. The onset and duration of sleep of MESD-III and VI was more significant as compared to MESD-I, II, IV and V. It is clear from the literature that sedative properties possessing drugs prolong sleeping time produced by barbiturates (Nyeem et al., 2006). It is an index for CNS depression when barbiturates potentiate hypnosis (Birhanie et al., 2016). Decrease in latency of sleep and sleeping time elongation are linked to CNS depressant agents. It may therefore be suggested that the stem bark and leaves extracts in prolonging barbiturate-induced sleeping time is due to the presence of central nervous system depressant agents.

The crude methanolic extract of Sterculia diversifolia stem bark and leaves were screened for analgesic response through centrally acting as well peripherally acting phenomenon. The effect produced by crude MESD stem bark and leaves was dose dependent. The analgesic response of crude MESD stem bark was more significant as compare to crude MESD leaves. The acetic acid induced pain model is a common, sensitive, easy and rapid technique for peripheral analgesic effect determination of crude extracts as well as other drugs (Naz et al., 2017). It is considered that writhing occurrence in mice is due to the involvement of local receptors e.g. peritoneal receptors. (Bentley et al., 1983). These peritoneal receptors are very much sensitive to prostaglandins as mentioned in literature. It is assumed that with acetic acid induced pain model, prostanoids production increased the peritoneal fluids and it served as pain mediators (Duarte et al., 1987). While hot plate test is applied to determine supra-spinal analgesia which is actually a spinal reflex test. This test is selectively used to determine the analgesic effect of centrally acting analgesic drugs. Those analgesic drugs which act peripherally are found inactive on hot plate test (Shojaii et al., 2015). Thus it is assumed that crude MESD stem bark and leaves possess active substance(s) which produce analgesic effect. Therefore it is suggested that these mechanism of actions are linked with pain mediators.

The evaluation of in-vivo anti-inflammatory activity of Sterculia diversifolia stem bark and leaves is determined by Carrageenan induced paw edema model. Pre-treatment with MESD stem bark and leaves significantly alleviated the carrageenan elicited paw edema after 2 and 3 hours at doses of $100 \mathrm{mg} / \mathrm{kg}(\mathrm{p}<$ 0.05 and $\mathrm{p}<0.01), 200 \mathrm{mg} / \mathrm{kg}(\mathrm{p}<0.05$ and $\mathrm{p}<0.001)$ and $300 \mathrm{mg} / \mathrm{kg}(\mathrm{p}<0.01$ and $\mathrm{p}<0.001)$ showing same results. Maximum anti-inflammatory effect was demonstrated by crude MESD-III ( $3^{\text {rd }}$ hour) and MESDVI ( $4^{\text {th }}$ hour $)$ at a dose of $300 \mathrm{mg} / \mathrm{kg}(\mathrm{p}<0.001)$. It means there might be some secondary metabolites, which have slow onset of action and long duration of action. The invivo anti-inflammatory activity of Sterculia diversifolia stem bark and leaves indicated that the biphasic inflammatory events produced by carrageenan were significantly controlled by the crude extracts, thus can be used as a potential anti-inflammatory agent. In various stages of carrageenan induced paw oedema, different mediators are involved. The first phase (90-180 min) of inflammation is the result of the release of histamine, serotonin and similar substances. The second phase (270$360 \mathrm{~min}$ ) of swelling is characterized by the increased volume of hind limb, during which the volume of edema reaches to the its highest point due to the presence of inflammatory mediators e.g. prostaglandins (Iqbal et al., 2017). The edema development after carrageenan subplantar injection in the animals is attributed to histamine, kinins, serotonins and prostaglandins release (Akindele \& Adeyemi, 2007).

The crude extract of Sterculia diversifolia stem bark and leaves was screened for antipyretic activity. The antipyretic effect produced by crude MESD stem bark and leaves, showed reduction in body temperature significantly after 3 hours at a dose of $200 \mathrm{mg} / \mathrm{kg}(p<$ $0.001)$ and $300 \mathrm{mg} / \mathrm{kg}(p<0.001)$ and this effect persisted till the $5^{\text {th }}$ hour. A dose dependent reduction in mice temperature was observed pre-treated with the stem bark and leaves extracts. The extracts of Sterculia diversifolia stem bark and leaves act both centrally and peripherally. These extracts reduces pyrexia by decreasing the brain concentration of $\mathrm{PGE}_{2}$ especially through its action on COX-3 in hypothalamus. It shows that some secondary metabolites are present in both extracts which may be responsible for prostaglandin inhibition (Zakaria et al., 2008).

Conclusion: In conclusion, extracts of Sterculia diversifolia stem bark and leaves possess potent anticonvulsant, CNS depressant, analgesic, antiinflammatory and antipyretic activities. Phytochemical analysis revealed that Sterculia diversifolia contained flavonoids e.g. luteolin, isoquercitrin and triterpenoids e.g. ursolic acid that might be concerned with in-vivo activities as mentioned above. The involvement of other secondary metabolites cannot be ignored. However, further studies are necessary like HPLC with Diode Array Detection profile to characterize the exact secondary metabolite responsible for these valuable biological effects.

\section{List of abbreviations}

G. Don George Don

2 D NMR Two dimensional Nuclear Magnetic Resonance

$1 \mathrm{H}$ NMR Proton Nuclear Magnetic Resonance

${ }^{13}$ C-NMR Carbon-13 NMR

EIMS Electron ionization mass spectrometry 


$\begin{array}{ll}\text { DCM } & \text { Dichloromethane } \\ \text { EtoAc } & \text { Ethyl Acetate } \\ \text { MESD } & \text { Methanolic extract of Sterculia diversifolia } \\ \text { UV } & \text { Ultra violet } \\ \text { IR } & \text { Infra Red } \\ \text { HPLC } & \text { High performance liquid chromatography } \\ \text { ICCBS } & \text { International center of chemical and biological } \\ & \text { sciences } \\ \text { ICDDR.B } & \text { International Centre for Diarrhoeal Disease } \\ & \text { Research, Bangladesh }\end{array}$

Acknowledgements: We express our gratitude to Department of Pharmacy, University of Peshawar, Peshawar, Pakistan for providing us research facility. Further we also like to extend our gratitude to Hussain Ebrahim Jamal Research Institute of Chemistry, ICCBS, University of Karachi, Karachi, Pakistan.

Conflict of interest statement: The authors declare that there is no conflict of interest.

\section{REFERENCES}

Akindele, A. and O. Adeyemi (2007). Antiinflammatory activity of the aqueous leaf extract of Byrsocarpus coccineus. Fitoterapia. 78(1): 2528.

Alam, M., A. Khan, A. Wadood, A. Khan, S. Bashir, A. Aman, A.K. Jan, A. Rauf, B. Ahmad and A.R. Khan (2016). Bioassay-guided isolation of sesquiterpene coumarins from Ferula narthex Bioss: a new anticancer agent. Front. Pharmacol. 7(26): 444-455.

Balaji, P., M. Thirumal, B. Kumudhaveni, G. Kishore and A. Aliya (2012). Central nervous system depressant activity of Barringtonia acutangula (Linn.) Gaertn. Der. Pharm. Lett. 4(6): 17861792.

Barkatullah, I.M., N. Muhammad and A. Rauf (2013). Antipyretic and antinociceptive profile of leaves of Skimmia laureola. Middle-East. J. Sci. Res. 14(8): 1124-1128.

Bentley, G., S. Newton and J. Starr (1983). Studies on the antinociceptive action of $\alpha$-agonist drugs and their interactions with opioid mechanisms. Br. J. Pharmacol. 79(1): 125-134.

Birhanie, M.W., B. Walle and K. Rebba (2016). Hypnotic effect of the essential oil from the leaves of Myrtus communis on mice. Nat. Sci. Sleep. 8(1): 267-275.

Buist, M., C.J. Yates and P.G. Ladd (2000). Ecological characteristics of Brachychiton populneus (Sterculiaceae)(kurrajong) in relation to the invasion of urban bushland in south-western Australia. Austral. Ecol. 25(5): 487-496.

Chokroverty, S., S. Bhat and R.P. Allen (2017). Sleep Disorders Medicine. Springer; New York (USA). pp. 713-757.
Dhayabaran, D., J. Florance and N. Krsihnadas (2012). Anticonvulsant activity of alcoholic root extract of Cardiospermum halicacabum. Rev. Bras. Farmacogn. 22(3): 323-329.

Duarte, I., M. Nakamura and S. Ferreira (1987). Participation of the sympathetic system in acetic acid-induced writhing in mice. Braz. J. Med. Biol. Res. 21(2): 341-343.

Fan, X., K. Du, N. Li, Z. Zheng, Y. Qin, J. Liu, R. Sun and Y. Su (2018). Evaluation of anti-nociceptive and anti-inflammatory effect of luteolin in Mice. J. Environ. Pathol. Toxicol. Oncol. 37(4): 351364.

Ghori, S.S., M.S. Qureshi, M.S.A. Khan, A. Khanam and J. Patel (2011). Anticonvulsant Activity of Leaf Extracts of Anacardium occidentale. Linn. Res. J. Pharmacol. Pharmacodyn. 3(2): 72-76.

Guo, J., C. Xue, J. Duan, D. Qian, Y. Tang and Y. You (2011). Anticonvulsant, antidepressant-like activity of Abelmoschus manihot ethanol extract and its potential active components in vivo. Phytomed. 18(14): 1250-1254.

Gurib-Fakim, A. (2006). Medicinal plants: traditions of yesterday and drugs of tomorrow. Mol. Aspects. Med. 27(1): 1-93.

Hussain, F., S.K. Poddar, A. Ganguly and S.A. Rahman (2016). Investigation of CNS depressant, antidiarrheal and cytotoxic activities of crude methanolic extracts of Acacia nilotica and Justicia adhatoda root. Indo Am. J. Pharm. Res. 16(1): 3954-3961.

Iqbal, A., I. Siraj-ud-Din, G. Ali, Z.U. Rahman, F. Rabi and M.S. Khan (2017). Pharmacological Evaluation of Tamarix aphylla for Antiinflammatory, Anti-pyretic and Anti-nociceptive Activities in Standard Animal Models. W. Indian. Med. https://doi.10.7727/wimj.2016.7346.

Jamshed, S., A. Ullah and A. Rashid (2014). Tree species and their associated conservation issues at Hayatabad township, Khyber Pakthunkhwa Peshawar, Pakistan. Int. J. Biol. Biotechnol. 11(2): 309-317.

Khan, H., M. Saeed, M.A. Khan, A. Dar and I. Khan (2010). The antinociceptive activity of Polygonatum verticillatum rhizomes in pain models. J. Ethnopharmacol. 127(2): 521-527.

Khan, H., M. Saeed, N. Muhammad, R. Ghaffar, S.A. Khan and S. Hassan (2012). Antimicrobial activities of rhizomes of Polygonatum verticillatum: attributed to its total flavonoidal and phenolic contents. Pakistan J. Pharm. Sci. 25(2): 463-467.

Khan, I., M. Nisar, F. Ebad, S. Nadeem, M. Saeed, H. Khan, F. Khuda, N. Karim and Z. Ahmad (2009). Anti-inflammatory activities of 
Sieboldogenin from Smilax china Linn.: experimental and computational studies. J. Ethnopharmacol. 121(1): 175-177.

Muhammad, N., M. Saeed and H. Khan (2012). Antipyretic, analgesic and anti-inflammatory activity of Viola betonicifolia whole plant. BMC Complement. Alter. Med. 12(1): 59-66.

Naz, H., A. Bashir, S. Naz, K.U. Rahman, A. Rauf, S.U.A. Shah, S. Fatmawati, S. Patel and S. Bawazeer (2017). A mechanistic approach to antidiarrheal and analgesic potentials of active secondary metabolites from encapsulated probiotics. Biomed. Res. 28(20): 8790-8794.

Nieoczym, D., K. Socała and P. Wlaź (2018). Assessment of the anticonvulsant potency of ursolic acid in seizure threshold tests in mice. Neurochem. Res. 43(5): 995-1002.

Nyeem, M., M. Alam, M. Awal, M. Mostofa, S. Uddin, N. Islam and R. Rouf (2006). CNS depressant effect of the crude ethanolic extract of the flowering tops of Rosa Damascena. Iran. J. Pharmacol. Ther. 5(2): 171-174.

Rabbi, F., A. Zada, A. Adhikari, A. Jabeen, A. Nisar and I. Ullah (2017). Sterculia diversifolia bears anticancer and immunomodulatory activities. Bangladesh. J. Pharmacol. 12(1): 51-55.

Rabbi, F., A. Zada and A. Nisar (2020a). Larvicidal, leishmanicidal, insecticidal and anthelmintic effects of Sterculia diversifolia stem bark and leaf. Bangladesh. J. Pharmacol. 15(1): 32-38.

Rabbi, F., A. Zada, A. Nisar, M. Sohail, S.K. Khalil and W.A. Shah (2020b). Bioassay-Guided Isolation, Identification of Compounds from Sterculia diversifolia and Investigation of Their AntiGlycation and Antioxidant Activities. Pharm. Chem. J. 53(12): 1137-1144.

Rabbi, F., A. Zada, A. Adhikari, A. Nisar and S.K. Khalil (2020c). Chemical constituent with cytotoxicity from Sterculia diversifolia. J. Asian. Nat. Prod. Res.https://doi.org/10.1080/10286020.10282020 .11791099 .

Rai, S.N., W. Zahra, S.S. Singh, H. Birla, C. Keswani, H. Dilnashin, A.S. Rathore, R. Singh, R.K. Singh and S.P. Singh (2019). Anti-inflammatory activity of ursolic acid in MPTP-induced parkinsonian mouse model. Neurotox. Res. 36(3): 452-462.

Rogerio, A., A. Kanashiro, C. Fontanari, E. Da Silva, Y. Lucisano-Valim, E. Soares and L. Faccioli (2007). Anti-inflammatory activity of quercetin and isoquercitrin in experimental murine allergic asthma. Inflamm. Res. 56(10): 402-408.
Salem, M.Z.M., H.M. Ali and M.M. Mansour (2014). Fatty acid methyl esters from air-dried wood, bark, and leaves of Brachychiton diversifolius R. Br: Antibacterial, antifungal, and antioxidant activities. BioResources. 9(3): 3835-3845.

Shaikh, M.F., K.N. Tan and K. Borges (2013). Anticonvulsant screening of luteolin in four mouse seizure models. Neurosci. Lett. 550(1): 195-199.

Shojaii, A., M. Motaghinejad, S. Norouzi and M. Motevalian (2015). Evaluation of Antiinflammatory and Analgesic Activity of the Extract and Fractions of Astragalus hamosus in Animal Models. Iran. J. Pharm. Res. 14(1): 263269.

Tambe, R., A. Patil, P. Jain, J. Sancheti, G. Somani and S. Sathaye (2017). Assessment of luteolin isolated from Eclipta alba leaves in animal models of epilepsy. Pharm. Biol. 55(1): 264268.

Taviano, M., N. Miceli, M. Monforte, O. Tzakou and E. Galati (2007). Ursolic acid plays a role in Nepeta sibthorpii Bentham CNS depressing effects. Phytother. Res. 21(4): 382-385.

Ur Rahman, S., M. Ismail, M. Khurram, I. Ullah, F. Rabbi and M. Iriti (2017). Bioactive steroids and saponins of the genus Trillium. Molecules. 22(12): 2156.

Vasconcelos, S.M., N.M. Lima, G.T. Sales, G.M. Cunha, L.M. Aguiar, E.R. Silveira, A.C. Rodrigues, D.S. Macedo, M.M.F. Fonteles and F.C.F. Sousa (2007). Anticonvulsant activity of hydroalcoholic extracts from Erythrina velutina and Erythrina mulungu. J. Ethnopharmacol. 110(2): 271-274.

Vyawahare, N., A. Khandelwal, V. Batra and A. Nikam (2007). Herbal anticonvulsants. J. herb. Med. Toxicol. 1(1): 9-14.

Wei, L., W. Zhang, L. Yin, F. Yan, Y. Xu and F. Chen (2015). Extraction optimization of total triterpenoids from Jatropha curcas leaves using response surface methodology and evaluations of their antimicrobial and antioxidant capacities. Electron. J. Biotechnol. 18(2): 88-95.

Zakaria, Z.A., Z.D.F.A. Ghani, R.N.S.R.M. Nor, H.K. Gopalan, M.R. Sulaiman, A.M.M. Jais, M.N. Somchit, A.A. Kader and J. Ripin (2008). Antinociceptive, anti-inflammatory, and antipyretic properties of an aqueous extract of Dicranopteris linearis leaves in experimental animal models. J. Nat. Med. 62(2): 179-187. 